\title{
URZECZYWISTNIENIE ZASADY ZRÓWNOWAŻONEGO ROZWOJU PRZEZ WSPÓŁDZIAŁANIE INTERESU PRYWATNEGO I PUBLICZNEGO
}

\section{Wprowadzenie}

Zasada zrównoważonego rozwoju występuje zarówno w aktach należących do prawa międzynarodowego, ${ }^{1}$ unijnego, ${ }^{2}$ a także krajowego. W polskim porządku prawnym oprócz ujęcia jej w Konstytucji, jest formułowana i wymieniania również przez akty niższego rzędu - ustawy ${ }^{3}$ czy rozporządzenia. ${ }^{4}$ Takie rozproszenie powoduje w konsekwencji, że zasadę tę prawodawca odnosi do różnych aspektów rzeczywistości, przez co ma ona bardzo szerokie znaczenie. ${ }^{5}$

Rozpoczynając od Ustawy zasadniczej, należy zauważyć, że w art. 5 Konstytucji ustalone zostały kierunki działania państwa, a w tym kompetencje i zadania organów państwowych. ${ }^{6}$ Czyni to $\mathrm{z}$ zasady zrównoważonego rozwoju instrument nadający kierunek działaniom administracji. Ale pełni ona również inne funkcje. Jest też podstawą działań planistycznych i służy kontroli prawidłowości i legalności realizacji przepisów prawa, będąc dyrektywą interpretacyjną realizacji przepisów u.p.z.p. oraz kontroli aktów planistycznych. ${ }^{7}$ Natomiast zgodnie z ustawą prawo

1 Por. m.in. art. 2 Konwencji UNESCO sporządzonej w Paryżu dnia 20 października 2005 r. w sprawie ochrony i promowania różnorodności form wyrazu kulturowego (Dz.U. z 2007 r. Nr 215, poz.1585).

Por. m.in. art. 191 ust. 3 Traktatu o funkcjonowaniu Unii Europejskiej (Dz.U. z 2004 r. Nr 90, poz. 864/2); m.in. pkt 15 Preambuła, art. 2 ust. 2 pkt e Rozporządzenie WE nr 1638/2006 Parlamentu Europejskiego i Rady z dnia 24 października 2006 r. określające przepisy ogólne w sprawie ustanowienia Europejskiego Instrumentu Sąsiedztwa i Partnerstwa (Dz.U.UE.L.2006.310.1).

Por. m.in. art. 1 pkt 2 ustawy z dnia 27 marca 2003 r. o planowaniu i zagospodarowaniu przestrzennym (Dz.U.2012.647 j.t.); art. 3 pkt 50 ustawy z dnia 27 kwietnia 2001 r. Prawo ochrony środowiska (Dz.U. z 2008 r. Nr 25, poz.150).

Por. m.in. Rozporządzenie Ministra Infrastruktury z dnia 25 maja 2011 r. w sprawie szczegółowego zakresu planu zrównoważonego rozwoju publicznego transportu zbiorowego (Dz.U. z 2011 r. Nr 117, poz. 684.

5 Jest to też efektem nieudolnego przekładu tego terminu z jego brzemienia obcojęzycznego.

6 Komentarz do art. 5 Konstytucji, [w:] W. Skrzydło, Konstytucja Rzeczypospolitej Polskiej, Kraków 2002, Lex/el

7 T. Bąkowski, Ustawa o planowaniu i zagospodarowaniu przestrzennym. Komentarz, Kraków 2004, Lex/el. 
ochrony środowiska (dalej: p.o.ś.), wyrażana jest ona przez ,(...) rozwój społecznogospodarczy, w którym następuje proces integrowania działań politycznych, gospodarczych i społecznych, z zachowaniem równowagi przyrodniczej oraz trwałości podstawowych procesów przyrodniczych, w celu zagwarantowania możliwości zaspokajania podstawowych potrzeb poszczególnych społeczności lub obywateli zarówno współczesnego pokolenia, jak i przyszłych pokoleń."

Powyższe ustalenia znajdują również odzwierciedlenie w doktrynalnych definicjach zasady zrównoważonego rozwoju. W literaturze podkreśla się, że wykracza ona poza ekorozwój obejmując oprócz niego również rozwój gospodarczy i społeczno-kulturowy, mimo że w dominującym nurcie pojęcie to kojarzone jest częściej z ochroną środowiska. ${ }^{8}$ Podkreśla się jednak pryzmat jej silnego związku z kontekstem społeczno-gospodarczym. ${ }^{9}$ Ze zrównoważonego rozwoju wywodzi się wymóg zachowania równowagi między sferą techniczną, duchową i przyrodniczą, międzyludzką, międzypokoleniową i międzynarodową, gwarantującą pomyślność ekonomiczną odporną na załamania i kryzysy. ${ }^{10}$ A tym samym przekłada się na zrównoważony rozwój sfer: społecznej, ekonomicznej i środowiskowej. ${ }^{11}$ Za szeroką wykładnią tego pojęcia stoi również orzecznictwo, w którym wskazuje się, że za pojęciem tym stoi oprócz ochrony środowiska również troska o rozwój społeczny i cywilizacyjny, związany z danym przedsięwzięciem. ${ }^{12}$

Oderwanie pojęcia zrównoważonego rozwoju od zagadnień dotyczących wyłącznie ekologii i odniesienie go do innych aspektów wydaje się być uzasadnione ze względów prakseologicznych. Przede wszystkim zrównoważony rozwój jest zjawiskiem mającym na celu łagodzenie konfliktów na linii państwo i podmiot niepaństwowy. Jego zrównoważenie polega na tym, że chroni interesy prywatne i publiczne, materialne i niematerialne, obecnego i przyszłych pokoleń. ${ }^{13}$

Nie ulega też wątpliwości, że przyjęcie takiej perspektywy umożliwia ukazanie zasadniczego dla niniejszego artykułu zagadnienia, jakim jest kwestia relacji interesu publicznego i prywatnego, wyodrębnionych tu z racji na kryterium przedmiotowe, t. j. ich treściową zawartość. $O$ ile kwestia znaczenia interesu publicznego nie powinna budzić wątpliwości, gdyż mimo braku jego uniwersalnej definicji legalnej, jego istota jest wręcz intuicyjnie zrozumiała, o tyle kwestia interesu prywatnego może wydawać się nieco niejasna. $Z$ tego względu określając jego znaczenie w ni-

T. Borys, Wąskie i szerokie interpretacje zrównoważonego rozwoju oraz konsekwencje wyboru (Narrow and broad interpretations of sustainable development concept and the choice consequences), [w:] Zrównoważony rozwój od utopii do praw człowieka, A. Papuziński (red.), Bydgoszcz 2005, s. 75.

9

Z. Bukowski, Pojęcie zrównoważonego rozwoju w prawie polskim (Concept of „sustainable development” in the polish law), [w]: Zrównoważony rozwój od utopii do praw człowieka, A. Papuziński (red.), Bydgoszcz 2005, s. 104. S. Kozłowski, Przyszłość ekorozwoju, Lublin 2005, s. 49.

11 Z. Niewiadomski (red.), Prawna regulacja procesu inwestycyjno-budowlanego. Uwarunkowania. Bariery. Perspektywy, Warszawa 2009, s. 337

12 Wyrok NSA w Warszawie z dnia 26 października 2011 r., II OSK 1820/11, LEX nr 1152061, Wyrok WSA w Warszawie z dnia 23 czerwca 2009 r., IV SA/Wa 1269/08, LEX nr 564009.

13 B. Wierzbowski, Gospodarka nieruchomościami. Podstawy prawne, Warszawa 2010, s. 86. 
niejszych rozważaniach należy podkreślić, że będzie on pojmowany przede wszystkim jako interes majątkowy, oparty w normach prawa prywatnego. Oznacza to, że może być to interes jedynie podmiotu niepublicznego, gdyż to on może jedynie dążyć do uzyskania korzyści majątkowych. Administracja publiczna podejmując swoje działania realizuje interes publiczny, który to jest nadrzędnym kierunkiem jej aktywności. To interes publiczny pełni funkcję legitymacyjną dla wszelkich jej działań i jest jednocześnie podstawowym kryterium ich oceny. ${ }^{14}$ Nie można jednak pomijać, że administracja publiczna mimo silnego związania $\mathrm{z}$ interesem publicznym nie jest monopolistą w przedmiocie jego realizowania. Celem realizacji tego interesu mogą również działać podmioty nie wchodzące do sfery podmiotów władzy publicznej. ${ }^{15}$

Przez tak ukazane kryterium interesu powstają zatem dwie grupy podmiotów ważne dla całości przedmiotowych rozważań - publiczna reprezentowana przez administrację publiczną oraz prywatna, w której odnajdujemy podmioty usytuowane na zewnątrz administracji. O ile jednak linia ich rozróżnienia biegnie według kryterium interesu prywatnego, o tyle interes publiczny i jego realizację można uznać za ich element wspólny.

Takie ustalenie koreluje z opisanym wyżej szerokim rozumieniem zasady zrównoważonego rozwoju. Przede wszystkim interes prywatny w takim ujęciu wiązać się będzie $\mathrm{z}$ wieloma sferami strukturalnymi zasady zrównoważonego rozwoju. Oczywiście to dla administracji publicznej zasada ta ustanawia podstawy kompetencyjne działania, a także jej urzeczywistnienie leży w interesie publicznym. Ale w przypadku realizacji tej zasady istotną rolę odgrywają też podmioty niepubliczne. Zasada zrównoważonego rozwoju pozwala zauważyć, że pomiędzy interesem prywatnym a publicznym nie zawsze musi istnieć stan konfliktu. Oba bowiem interesy mogą dążyć do tych samych celów i w tym zakresie się wspierać. ${ }^{16}$ Dlatego też można stwierdzić, że w tej kwestii możliwe jest zauważenie kilku perspektyw relacji pomiędzy interesem publicznym i prywatnym powstałych właśnie w kontekście zasady zrównoważonego rozwoju. Pierwsza z nich łączy się przede wszystkim z wydźwiękiem tej zasady jako kierunku działania administracji publicznej. W tym znaczeniu podmioty administracji publicznej działając $\mathrm{w}$ duchu zasady zrównoważonego rozwoju i realizując tym samym interes publiczny wspomagają również realizację interesu prywatnego. Oddziałują bowiem na sfery istotne dla tego interesu, umożliwiając ich postęp. Do takiego samego rezultatu prowadzi również zinstytucjonalizowane współdziałanie administracji publicznej i sektora prywatnego, w tym też przekazanie przez administrację publiczną podmiotom niepublicznym jej kompetencji i zadań do wykonania, przez co podmiot niepubliczny realizuje swoimi działaniami zarówno swój interes prywatny, jak również interes publiczny. Powyższe uzupeł-

14 S. Dudzik, Działalność gospodarcza samorządu terytorialnego. Problematyka prawna, Kraków 1998, s. 197.

15 E. Schmidt-Aßmann, Ogólne prawo administracyjne jako idea porządku. Założenia i żądania tworzenia systemu prawa administracyjnego, Warszawa 2011, s. 192. 
nia fakt, że zrównoważony rozwój zasadniczo zakłada nie tyle postęp w objętych nim sferach, co ich współdziałanie i przez to zabezpieczenie wszelkich interesów. Polega zatem na uwzględnianiu interesu prywatnego przez podmioty legitymujące się interesem publicznym i na odwrót i współdziałaniu ze sobą interesu publicznego z prywatnym, przez co może ona dopiero zostać w pełni urzeczywistniona i osiągnąć wyznaczone jej cele, służące zarazem interesowi publicznemu, jak również interesowi prywatnemu.

Z punktu widzenia niniejszych rozważań najważniejszy jest aspekt zakładający właśnie współpracę podmiotów wykonujących administrację publiczną z podmiotami niepublicznymi - dysponentami interesu prywatnego (t. j. tymi, których głównym celem działalności jest pozyskiwanie zysku (przedsiębiorcy), jak również tymi, dla których uzyskanie korzyści majątkowej jest jedynie celem pobocznym i środkiem realizacji celu nadrzędnego - organizacje pozarządowe). Takie określenie partnerów powoduje również, że działania realizowane przez współdziałanie interesów publicznego i prywatnego mogą dotyczyć wielu sfer ujętych w zasadzie zrównoważonego rozwoju - kwestii gospodarczych ściśle związanych z pojęciem zysku, ale również kwestii istotnych dla rozwoju społecznego, czy ochrony środowiska. Charakter podmiotu niepublicznego wpływa również na sposób współdziałania z nim podmiotów administracji publicznej. Współpraca ta różna będzie zarówno w przypadku przedsiębiorców, jak i ngo.

Współdziałanie interesu prywatnego i publicznego wynikające z powyższych wniosków związane jest przede wszystkim ze zjawiskiem prywatyzacji zadań publicznych t.j. przekazania zadań publicznych przypisanych administracji publicznej podmiotom niepublicznym. ${ }^{17} \mathrm{Z}$ tego względu to te zagadnienie stanowić będzie zasadniczy punkt odniesienia niniejszych rozważań. Nie bez znaczenia pozostaje w tym wypadku tworzenie przez administrację publiczną warunków do rozwoju danej sfery oraz kolejny kontekst współdziałania tych interesów, jakim jest przede wszystkim dialog tych dwóch grup zainteresowana (publicznej i prywatnej) i ich współpraca w zakresie wypracowywania wspólnych rozwiązań. Oznacza to wobec tego otwarcie szerokiej perspektywy współdziałania tych interesów i urzeczywistniania przez nie zasady zrównoważonego rozwoju.

Najistotniejsza jest tu prywatyzacja działań administracji publicznej, polegająca na współdziałaniu sfery publicznej i prywatnej, którą można obserwować zarówno na gruncie stanowienia prawa, jak i jego stosowania. Istnieją szczegółowe regulacje ustawowe bezpośrednio umożliwiające przekazanie wykonywania zadań publicznych podmiotom usytuowanym poza sferą administracji, jak np. w rozdziale

17 A. Błaś, Formy działania administracji w warunkach prywatyzacji zadań publicznych, [w:] Administracja i prawo administracyjne u progu trzeciego tysiąclecia. Materiały Konferencji Naukowej Katedr Prawa i Postępowania Administracyjnego, Łódź 2000, s. 23; L. Zacharko, Prywatyzacja zadań publicznych w nauce niemieckiej, ST 1996, nr 3, s. 31 . 
4 ustawy z dnia 22 sierpnia 1997 r. o ochronie osób i mienia. ${ }^{18} \mathrm{Z}$ drugiej jednak strony prawo tworzy również ogólne mechanizmy wspierające tendencję prywatyzacji i umożliwiające urzeczywistnienie tej współpracy zasadniczo niezależnie od pola działalności administracji publicznej. Dzieje się tak w szczególności w przypadku ustawy z dnia 19 grudnia 2008 r. o partnerstwie publiczno-prywatnym, ${ }^{19}$ czy o działalności pożytku publicznego i o wolontariacie. ${ }^{20}$ Co istotne, należy też zauważyć, że proces prywatyzacji w pewien sposób prowadzi do transformacji treści samego interesu publicznego, przez przekształcenie zadań publicznych, a ściślej formy ich wykonywania. Realizatorem celów interesu publicznego stają się podmioty niepubliczne, co stanowi bez wątpienia kolejny przejaw transformacji ustrojowej po decentralizacji zadań publicznych na rzecz samorządu terytorialnego. Należy podkreślić, że w żaden sposób nie wpływa to jednak bezpośrednio na wartości składające się na treść interesu publicznego i prywatnego. Nadal zatem mamy do czynienia $\mathrm{z}$ dwiema odrębnymi kategoriami.

U źródła zaś samego zjawiska prywatyzacji należy upatrywać przyczyn leżących zarówno po stronie podmiotów władzy publicznej i podmiotów prywatnych. W przypadku organów administracji publicznej prywatyzacja przede wszystkim prowadzi do ich odciążenia $\mathrm{z}$ wielu nałożonych na nie zadań. Kierując realizację zadań publicznych do podmiotów prywatnych administracja kieruje się przede wszystkim założeniem zapewnienia większej efektywności, a także profesjonalizmem świadczeń i maksymalizacji usług publicznych. Nadal też ma na nie wpływ przez sprawowanie kontroli, czy nadzoru wykonywania tych zadań.

Dla podmiotu prywatnego ma to szczególnie doniosłe skutki. Przede wszystkim nie można pomijać, że przekazanie mu zadania publicznego nie może spowodować ograniczenia ilości, dostępności oraz jakości usług publicznych. ${ }^{21}$ Podmiot prywatny jest zobowiązany podjąć wszelkie działania faktyczne i prawne prowadzące do sprostania tym wymogom. Umożliwia to przede wszystkim zespół jego cech, które przekonują administrację publiczną do współpracy z nim: większa jakość oraz ekonomiczna i społeczna efektywność świadczonych usług i wynikające z jego doświadczenia kreatywność, innowacyjność. Konieczne jest, by współdziałanie tych różnych sektorów było ukształtowane w taki sposób, aby podmioty publiczne i niepubliczne wykonując zadania działały tak, by zrealizowany został zarówno interes publiczny, jak również nastąpiło osiągnięcie wyznaczonych celów definiowanych interesem prywatnym. Realizacja celów interesu prywatnego umożliwia bowiem dalsze współdziałanie podmiotu niepublicznego z podmiotami władzy publicznej

18 Ustawa z dnia 22 sierpnia 1997 r. o ochronie osób i mienia (Dz.U. z 2005 r. Nr 145, poz. 1221).

19 Ustawa z dnia 19 grudnia 2008 r. o partnerstwie publiczno-prywatnym (Dz.U. z 2009 r. Nr 19, poz. 100).

20 Ustawa z dnia 24 kwietnia 2003 r. o działalności pożytku publicznego i o wolontariacie (Dz.U. z 2010 r. Nr 234 , poz. 1536).

21 E. Knosala, Zadania publiczne, formy organizacyjno-prawne ich wykonywania i nowe pojęcia - zakres niektórych problemów do dyskusji nad koncepcją systemu prawa administracyjnego, [w:] Koncepcja systemu prawa administracyjnego, J. Zimmermann (red.),Warszawa 2007, s. 123. 
i rozwijanie tej współpracy. Daje potrzebne środki, a także zapewnia stabilne i jasne warunki współpracy.

\section{Realizowanie zasady zrównoważonego rozwoju przez przedsiębiorców}

Współdziałanie interesu publicznego i prywatnego, w kontekście współpracy administracji publicznej z przedsiębiorcami, jest bardziej korzystnym zjawiskiem, aniżeli pełna publicyzacja. Wynika to przede wszystkim z tego, że obecnie państwo samo w sobie nie może być uznawane za adresata konstytucyjnych praw ekonomicznych. Na pierwszy plan wysunęła się bowiem jego rola ich gwaranta. ${ }^{22}$ Wobec czego, coraz częściej podmioty władzy publicznej pełnią raczej rolę inspiratora i funkcję ochronną oraz nadzorczą wobec działań podejmowanych przez przedsiębiorców. ${ }^{23}$

Przykładem realizacji zasady zrównoważonego rozwoju przez administrację publiczną i przedsiębiorców jest przede wszystkim koncepcja partnerstwa publicznoprywatnego. Celem partnerstwa samego w sobie jest przede wszystkim uzgadnianie wspólnych celów i sposobów ich realizacji. ${ }^{24} \mathrm{~W}$ przypadku partnerstwa publicznoprywatnego w znaczeniu szerokim mamy do czynienia ze współpracą każdego rodzaju, jaka ma miejsce między sektorem publicznym i prywatnym, mającą na celu realizację szeroko pojętego dobra publicznego oraz przy realizacji dużych inwestycji użyteczności publicznej ${ }^{25}$ Natomiast w znaczeniu ścisłym jest to współpraca nawiązana pomiędzy jednostkami administracji rządowej i samorządowej (administracji publicznej) a podmiotami prywatnymi w sferach zazwyczaj kontrolowanych przez administrację, jak np. gospodarka komunalna, czy też obsługa społeczno-socjalna. Jest to współpraca realizowana w oparciu o umowę długoterminową, zawartą pomiędzy podmiotem publicznym i prywatnym, której celem jest stworzenie składników infrastruktury umożliwiającej świadczenie usług o charakterze publicznym. ${ }^{26}$ Partnerstwo umożliwia wobec tego realizowanie zadań publicznych w oparciu o umowy, co stanowi kuszącą alternatywę dla samodzielności ich wykonania przez administrację, czy też organizowania ich realizacji w trybie zamówień publicznych albo też przez konstrukcję odrębnych jednostek administracyjnych. ${ }^{27}$ Do pozostałych korzy-

T. Rabska, Działania administracji publicznej w świetle współczesnej koncepcji publicznego prawa gospodarczego, [w:] B. Popowska, K. Kokocińska, Instrumenty i formy prawne działania administracji gospodarczej, Poznań 2009, s. 19.

K. Rzetelska, Wycofanie się państwa z publiczno-prawnego wykonywania zadań, PUG 2004, nr 10, s. 25 i n.; A. Miruć, Partnerstwo publiczno-prywatne jako sposób realizacji zadań publicznych, [w:] Koncepcja systemu prawa administracyjnego, J. Zimmermann (red.), Warszawa 2007, s. 473.
T. Borys, Partnerstwo publiczno-prywatne w koncepcji zrównoważonego rozwoju, FK 2003, nr 4, s. 8. Por. A. Miruć, Partnerstwo publiczno-prywatne jako sposób realizacji zadań publicznych, [w:] J. Zimmermann (red.), Koncepcja systemu prawa administracyjnego, Warszawa 2007.

M. Bejm (red.),Ustawa o partnerstwie publiczno-prywatnym, Warszawa 2010, s. 8 i n.

D. Kijowski, Umowy w administracji publicznej, [w:] Podmioty administracji publicznej i prawne formy ich działania. Studia i materiały z konferencji naukowej poświęconej jubileuszowi 80-tych urodzin Profesora Eugeniusza Ochendowskiego, Toruń 2005, s. 290 i n. 
ści należy przede wszystkim to, że korzystając z partnerstwa publiczno-prywatnego administracja publiczna w założeniu nie dość, że zmniejsza zakres działań wymagających jej pełnej aktywności i skupia się ściślej na innych, to dodatkowo osiąga wskazane już wyżej cele związane z jakością i profesjonalizmem świadczonych usług. Co najistotniejsze, następuje również w tym wypadku podział ryzyka i zadań, co wpływa na efektywność realizacji całości przedsięwzięcia. Interes publiczny zostaje wobec tego w tym zakresie zrealizowany, a same jego urzeczywistnienie zostaje zabezpieczone powyżej wskazanymi okolicznościami determinującymi również wybór partnera prywatnego. Odnośnie interesu prywatnego należy wskazać, że pełni on również istotną rolę w tej relacji. Podmiot niepubliczny obok tego, że realizuje na mocy zawartej umowy cele publiczne wyznaczone interesem publicznym i może czerpać korzyści z wymiany doświadczeń ze stroną publiczną, ${ }^{28}$ partycypuje w nim również celem realizacji swojego interesu prywatnego. Ponadto, nie ulega też wątpliwości, że interes ten kształtują również posiadane zasoby podmiotu prywatnego. A co za tym idzie, o jego wyborze na partnera będą również decydowały jego możliwości finansowe, a także chęć uzyskania korzyści. Wynika to z tego, że zgodnie $z$ art. 6 ust. 2 pkt 2 u.p.p.p., jednym z kryteriów oceny ofert podmiotów niepublicznych jest termin i wysokość przewidywanych płatności lub innych świadczeń podmiotu publicznego, jeżeli są one planowane. Oznacza to, że nie można wykluczyć, że często chęć uzyskania jak najmniejszego zysku przez podmiot niepubliczny będzie wpływać pozytywnie na rozpatrzenie oferty. W konsekwencji, poddaje to pod wątpliwość, czy rzeczywiście można mówić o współdziałaniu i co za tym idzie równym traktowaniu interesu prywatnego i publicznego. Należy jednak wskazać, że w założeniu powinny jednak nawet $\mathrm{w}$ tym wypadku działać pewne zasady rynkowe zapewniające przede wszystkim konkurencyjność. Partnerstwo publiczno-prywatne jest bowiem umową, a co za tym idzie charakteryzuje się dobrowolnością. Partner prywatny powinien być zatem przekonany o tym, że jego zaangażowanie w przedsięwzięcie przyniesie również oczekiwane korzyści.

Powyższe wnioski doprowadziły do sedna istotnego aspektu współdziałania dwóch interesów w partnerstwie publiczno-prawnym, jakim jest zysk niepublicznego partnera. Zasadniczym pojęciem dla interesu prywatnego w tym zakresie jest przede wszystkim wkład własny zdefiniowany w art. 2 pkt 5 u.p.p.p. jako świadczenie materialne podmiotu publicznego lub partnera prywatnego oraz wynagrodzenie dla podmiotu prywatnego, które to stanowi element składowy umowy partnerstwa publiczno-prywatnego (por. art. 7 ust. 1 u.p.p.p.).

Wkład własny stanowi specyficzną konstrukcję, która łączyć się może dla partnera prywatnego zarówno w kwestią zysku, jak i koniecznością poniesienia nakładów. Wkład taki może bowiem wnieść zarówno podmiot publiczny, jak i prywatny. 
Przedsięwzięcie w ramach partnerstwa powinno zostać zrealizowane wspólnie, czyli w sytuacji, gdy partner prywatny zobowiąże się do realizacji przedsięwzięcia za wynagrodzeniem oraz poniesienia w całości albo w części wydatków na jego realizację lub poniesienia ich przez osobę trzecią. Natomiast podmiot publiczny zobowiązuje się do współdziałania w osiągnięciu celu przedsięwzięcia, w szczególności właśnie poprzez wniesienie wkładu własnego. Wkładem własnym podmiotu publicznego jest świadczenie polegające głównie na poniesieniu części wydatków na realizację przedsięwzięcia, w tym np. na sfinansowaniu dopłat do usług świadczonych przez partnera prywatnego w ramach przedsięwzięcia lub wniesieniu składnika majątkowego, np. nieruchomości. W przypadku natomiast partnera prywatnego będzie to np. dostarczenie zaplecza technicznego, gdyż jego głównym świadczeniem jest przede wszystkim realizacja przedsięwzięcia. Oznacza to, że wkład własny również w tym zakresie służy interesowi publicznemu, gdyż prowadzi do realizacji przedsięwzięcia, a w tym też zabezpiecza skuteczność jego finalizacji. W zakresie natomiast interesu prywatnego z jednej strony powoduje, że podmiot prywatny znosić musi uszczuplenie jego zasobów majątkowych, z drugiej jednak strony, odciążony zostaje on bowiem z obowiązku poniesienia dalszych nakładów z racji na możliwe zobowiązania w tej kwestii podmiotu publicznego.

Czystą korzyścią majątkową dla podmiotu niepublicznego działającego w ramach partnerstwa jest jednak wynagrodzenie. Nie ulega wątpliwości, że jego forma czyni z umowy partnerstwa publiczno-prywatnego akt inny niż cywilnoprawna umowa wzajemna, przez co w istotnym stopniu wpływa też na ukształtowanie interesu prywatnego. Podmiot niepubliczny owszem osiąga na skutek jej zawarcia korzyść $\mathrm{z}$ tytułu partycypacji w partnerstwie i osiąga wynagrodzenie, które może pochodzić od organów administracji publicznej w formie zapłaty sumy pieniężnej i być zyskiem w takiej wysokości, co wartość pracy świadczonej przez podmiot niepubliczny. Najczęściej jednak świadczenie podmiotu władzy publicznej nie będzie ekwiwalentne, gdyż umowa partnerstwa będzie umową niewzajemną, a nawet bezpłatną, gdzie wynagrodzenie zamykać się będzie w zysku, jaki przynosić będzie wprost zrealizowane przez podmiot prywatny przedsięwzięcie. ${ }^{29} \mathrm{~W}$ tym wypadku muszą to być pożytki wynikające wprost z partnerstwa. Dopuszczalne są również inne formy zaspokojenia interesu prywatnego podmiotu niepublicznego, jak np. przeniesienie prawa własności, czy przelew prawa majątkowego. Stąd też należy ocenić, że wynagrodzenie w tej sytuacje pełni raczej rolę funkcjonalną, będąc wszelkim przysporzeniem dla podmiotu prywatnego pochodzącym od podmiotu publicznego. ${ }^{30}$

Komentarz do art. 7 u.p.p.p., [w:] W. Gonet, Komentarz do ustawy o partnerstwie publiczno-prywatnym. Wzory umów i pism, Warszawa 2009, LexPolonica. 
Niezależnie od tych wątpliwości, w partnerstwie publiczno-prywatnym interes prywatny zostaje zaspokojony przez osiągnięcie często bardzo wysokiej korzyści przez podmiot prywatny od administracji publicznej. Oznacza to wobec tego, że ma miejsce współdziałanie interesów publicznego i prywatnego. Nie bez znaczenia pozostaje również fakt, że w ramach partnerstwa obok rzeczywistych jego stron, biorą również udział inne podmioty, gdyż konieczny w nich jest udział wielu wykonawców i podwykonawców. W praktyce w partnerstwie może uczestniczyć zatem znaczna liczba przedsiębiorców wspomagających realizację danego celu partnerstwa. $Z$ tego też względu osiąga ono dalekosiężne skutki. Nie tylko bowiem zapewnia realizację celów społecznych, czy ekologicznych, wpływa też pozytywnie na pobudzenie sfery ekonomicznej wzmagając produkcję i usługi.

\section{Urzeczywistnianie zasady zrównoważonego rozwoju przez ngo}

W szerokim znaczeniu partnerstwa publiczno-prywatnego, wykraczającym daleko poza obecną regulację ustawową tego zagadnienia, ${ }^{31}$ mogą w nim brać udział również organizacje pozarządowe, co wynika również m.in. z art. 11 ust. 5 d.p.p.w. Należy jednak podkreślić, że mimo, iż w takim układzie one również pełniłyby funkcję podmiotu niepublicznego pochodzącego z sektora prywatnego, to znaczenie ich interesu prywatnego nie jest aż tak ważne, jak ma to miejsce w przypadku przedsiębiorstw. W przypadku organizacji pozarządowych cel w postaci zysku pełni rolę subsydiarną do ich działalność, zasadniczym powodem ich istnienia jest bowiem realizacja celów cennych dla społeczeństwa. Działania podjęte celem realizacji celu pożytku publicznego nie mogą być podejmowane przez przypadek, tak samo obok zasadniczej działalności. ${ }^{32}$ Tym samym ocenić należy, że mimo niepublicznego charakteru organizacje pozarządowe realizują interes publiczny.

Zgodnie z art. 4 ust. 1 ustawy z dnia 24 kwietnia 2003 r. o działalności pożytku publicznego i o wolontariacie ${ }^{33}$ wyliczenie celów pożytku publicznego, zadań publicznych, zawartych w tym przepisie jest enumeratywne. Wynika z niego, że organizacje pozarządowe działają m.in. na rzecz ochrony środowiska, czy łagodzenia dysproporcji społecznych. Oznacza to, że same bez udziału innych podmiotów wspomagają swoją działalnością zasadę zrównoważonego rozwoju. Z punktu widzenia jednak przedmiotowych rozważań najważniejszy wydaje się być ust. 2 tego przepisu, który określa podstawę wyznaczenia sfery współdziałania administracji publicznej i sfery pozarządowej w realizacji zadań publicznych, uzupełniony

31 Por. jednak art. 11 ust. 5 d.p.p.w. dopuszczający zlecenie wykonywania przez organizacje pozarządowe zadań publicznych w oparciu o partnerstwo publiczno-prywatne.

32 Wyrok WSA we Wrocławiu z 18 listopada 2009 r., I SA/Wr 1365/09, LexPolonica nr 2504878.

33 Ustawa z dnia 24 kwietnia 2003 r. o działalności pożytku publicznego i o wolontariacie (Dz.U. 2010 r. Nr 234, poz. 1536), dalej: d.p.p.w. 
o art. 5 d.p.p.w. statuujący zasady współpracy pomiędzy sektorem publicznym a organizacjami pożytku publicznego i obowiązek współpracy administracji publicznej z organizacjami pozarządowymi. Niebywałą rolę w zakresie współdziałania tych podmiotów odgrywa przede wszystkim zasada pomocniczości, przenosząca działalność administracyjną w sferę jak najbliższą jednostce, ${ }^{34}$ przez co współpraca tych dwóch sektorów odbywa się zasadniczo bez sformalizowanych procedur ${ }^{35}$ wymaganych np. przy partnerstwie publiczno-prywatnym. Jak wskazuje na to N. Kowal: „Organizacje obywatelskie często wytwarzają dobra i świadczą usługi efektywniej, to znaczy lepszej jakości i po niższych kosztach, niż mogą to zrobić organy administracji państwowej." ${ }^{36}$ Powyższe uzupełniają zasada jawności, uczciwej konkurencji.

Z powyżej opisanej, jak i innych zasad regulujących ten stosunek (suwerenności, partnerstwa oraz efektywności) wynikają istotne skutki dla współpracy administracji publicznej z tym tzw. trzecim sektorem. Przede wszystkim wynika z nich, że organy administracji powinny być nie tyle zobligowanie do współpracy z ngo, co przede wszystkim nią zainteresowane. Bez wątpienia sprawność i wysoka jakość funkcjonowania ngo wpływa pozytywnie na działalność administracji. Organizacje pozarządowe jako działające najbliżej obywateli wpływają nie tyle na rozwój społeczeństwa obywatelskiego, co przede wszystkim rozwiązują jego problemy. Dla administracji publicznej warte powinno być to, że organizacje tego typu często zajmują się kwestiami problematycznymi zanim trafią one do administracji powodując tym samym konieczność wykładania na to pieniędzy z budżetu podmiotu publicznego.

$\mathrm{Z}$ regulacji ustawowej współpracy wynika również charakter współdziałania podmiotów publicznych z sektorem organizacji pozarządowych. Mianowicie, współpraca ta może mieć zarówno charakter merytoryczny, jak i finansowy. Ustawa ta przewiduje wsparcie realizacji zadań publicznych przez organizacje przez udzielanie pożyczek, gwarancji i poręczeń na mocy innych przepisów prawa. ${ }^{37}$ Praktyka wskazuje, że materialny wymiar takiej pomocy może również przybrać formę bardziej aktywną ze strony administracji i polegać na udostępnianiu ngo pomieszczeń i sprzętu biurowego przez podmioty publiczne.

Inną pomocą finansową administracji publicznej skierowaną do organizacji pozarządowych są przede wszystkim dotacje, które stanowią podstawę materialną realizacji przez ngo powierzonych zadań publicznych, jak również są instrumentem wspierania ich działalności. Zgodnie z art. 69 ust. 4 pkt 1 lit. d ustawy o finansach publicznych do dotacji zaliczamy w szczególności wydatki budżetu państwa przeznaczone na finansowanie lub dofinansowanie zadań zleconych do realiza-

34 A. Gajda, Zasada pomocniczości, [w:] J. Barcz (red.), Unia Europejska. System prawny, porządek instytucjonalny, proces decyzyjny, Warszawa 2009, s. 168.

Wyjątkiem są np. konsultacje aktów prawa miejscowego oraz konsultacje i tworzenie programów współpracy wymagające przeprowadzenia ustalonej ustawowo procedury.

36 Komentarz do art. 11 ustawy o działalności pożytku publicznego i o wolontariacie, [w:] N. Kowal, Tworzenie i rejestracja organizacji pożytku publicznego. Komentarz, Kraków 2005, Lex/el.

37 Ustawa z dnia 8 marca 1990 r. o samorządzie gminnym (Dz.U. z 2001 r. Nr 142, poz. 1591 z późn. zm.). 
cji jednostkom niezaliczonym do sektora finansów publicznych, w tym fundacjom i stowarzyszeniom. Cel istnienia organizacji pozarządowych powoduje, że ich dofinansowywanie musi być wobec tego przejrzyste i pozbawione uznaniowości charakteryzującej często praktykę urzędniczą, co ma zapewniać konkurs ofert.

Administracja publiczna często decyduje się na powierzenie realizacji zadań publicznych z racji na kwestie ekonomiczne, celem ograniczenia wydatków w tym zakresie z uwagi na posiadanie własnych środków przez organizację publiczną. Organizacje pozarządowe czerpią środki nie tylko od administracji publicznej, na której spoczywa obowiązek finansowania zadania publicznego, lecz również pozyskują je w drodze cywilnoprawnej, jak np. pozyskiwanie darowizn, czy podpisanie stosownych kontraktów. ${ }^{38}$ Pomimo zatem, że z samego zlecenia (art. 13 ust. 1 pkt 2 d.p.p.w.) wynika konieczność wyłożenia przez organ administracji odpowiednich środków finansowych, organizacja pozarządowa może ich również poszukiwać we własnym zakresie, co pozwala ocenić również skuteczności takiego podmiotu. Przykładem również samodzielnego poszukiwania środków na rzecz realizacji zadań publicznych jest przede wszystkim możliwość prowadzenia przez organizacje pozarządowe działalności gospodarczej oraz odpłatnej działalności statutowej, nadal realizującej zadania publiczne. Co istotne, nie można prowadzić działalności gospodarczej i odpłatnej działalności pożytku publicznego co do tego samego celu ngo (art. 9 ust. 2 d. p.p.w.). Można z tego wywieść zatem rozgraniczenie działalności pożytku publicznego od działalności w zasadzie komercyjnej. Pozyskiwanie środków finansowych wskutek własnego działania ma być jedynie pomocnicze wobec zasadniczej działalności statutowej. Rodzi jednak pozytywne skutki dla działalności takich organizacji, a tym samym interesu publicznego i zasady zrównoważonego rozwoju. Powoduje bowiem stabilność finansową, a przez to zapewnia ciągłość działań i rozwój tego typu aktywności.

\section{Podsumowanie}

Reasumując poszczególne wnioski i przykłady można wskazać, że wszystkie są przejawami partnerstwa publiczno-prywatnego w znaczeniu szerokim. Ono zaś zakłada ścisłą współpracę interesu publicznego i prywatnego, która w konsekwencji prowadzi do ich zaspokojenia. Przy wskazanych wyżej przykładach współpracy sfery publicznej z szeroko rozumianą sferą prywatną następuje udział wielu czynników istotnych z punktu widzenia zasady zrównoważonego rozwoju, a jednocześnie też ma miejsce ich zbalansowany rozwój.

Konkludując już całość powyższych rozważań należy wskazać, iż zasada zrównoważonego rozwoju jest bardzo dynamiczna. Można uznać, że przedmiotowy dla tych rozważań problem jest możliwy do określenia przez dwie relacje: realiza- 
cji zasady zrównoważonego rozwoju przez udział interesu prywatnego i publicznego oraz bycie przez nią gwarantem ochrony tych interesów, wymagającym ich współdziałania.

Celem urzeczywistnienia zasady zrównoważonego rozwoju podejmowane są działania o różnym charakterze, przenikają się wszystkie sfery istotne dla rozwoju całej społeczności i kooperują ze sobą podmioty wywodzące się z różnych sektorów. Jednocześnie też takie zjawisko jest możliwe dlatego, że obowiązuje zasada gwarantująca sprzężenie wszystkich tych elementów. Powoduje to, że nie można w moim przekonaniu mówić, iż zasada zrównoważonego rozwoju jest jedynie podstawą działania administracji publicznej. Ukazany wyżej problem jej realizowania przez współdziałanie skrajnych interesów publicznego i prywatnego wskazuje, że jest ona urzeczywistniana również przez podmioty dalekie od administracji publicznej. To ich partycypacja umożliwia bowiem zaistnienie zrównoważonego rozwoju we wszystkich sferach i ich integracji. Zrównoważony rozwój ukazuje sprzężenie problemów społecznych, ekonomicznych i ekologicznych.

\section{BIBLIOGRAFIA}

Antoniuk J.R., Nowa regulacja partnerstwa publiczno-prywatnego, [w:] M. Urbaniec, P. Stec, S. Dolata (red.), Partnerstwo publiczno-prywatne jako instrument rozwoju zrównoważonego, Częstochowa 2009.

Bąkowski T., Ustawa o planowaniu i zagospodarowaniu przestrzennym. Komentarz, Kraków 2004.

Bejm M. (red.),Ustawa o partnerstwie publiczno-prywatnym, Warszawa 2010.

Błaś A., Formy działania administracji w warunkach prywatyzacji zadań publicznych, [w:] Administracja i prawo administracyjne u progu trzeciego tysiąclecia. Materiały Konferencji Naukowej Katedr Prawa i Postępowania Administracyjnego, Łódź 2000.

Borys T., Wąskie i szerokie interpretacje zrównoważonego rozwoju oraz konsekwencje wyboru (Narrow and broad interpretations of sustainable development concept and the choice consequences), [w:] Zrównoważony rozwój od utopii do praw człowieka, A. Papuziński (red.), Bydgoszcz 2005 .

Borys T., Partnerstwo publiczno-prywatne w koncepcji zrównoważonego rozwoju, FK 2003, nr 4.

Bukowski Z., Pojęcie zrównoważonego rozwoju w prawie polskim (Concept of „sustainable development" in the polish law), [w:] Zrównoważony rozwój od utopii do praw człowieka, A. Papuziński (red.), Bydgoszcz 2005.

Dudzik S., Działalność gospodarcza samorządu terytorialnego. Problematyka prawna, Kraków 1998.

Gajda A., Zasada pomocniczości, [w:] J. Barcz (red.), Unia Europejska. System prawny, porządek instytucjonalny, proces decyzyjny, Warszawa 2009.

Gonet W., Komentarz do ustawy o partnerstwie publiczno-prywatnym. Wzory umów i pism, Warszawa 2009. 
Kijowski D., Umowy w administracji publicznej, [w:] Podmioty administracji publicznej i prawne formy ich działania. Studia i materiały z konferencji naukowej poświęconej jubileuszowi 80-tych urodzin Profesora Eugeniusza Ochendowskiego, Toruń 2005.

Knosala E., Zadania publiczne, formy organizacyjno-prawne ich wykonywania i nowe pojęcia - zakres niektórych problemów do dyskusji nad koncepcją systemu prawa administracyjnego, [w:] Koncepcja systemu prawa administracyjnego, J. Zimmermann (red.), Warszawa 2007.

Kowal N., Tworzenie i rejestracja organizacji pożytku publicznego. Komentarz, Kraków 2005.

Kozłowski S., Przyszłość ekorozwoju, Lublin 2005.

Miruć A., Partnerstwo publiczno-prywatne jako sposób realizacji zadań publicznych, [w:] Koncepcja systemu prawa administracyjnego, J. Zimmermann (red.), Warszawa 2007.

Niewiadomski Z. (red.), Prawna regulacja procesu inwestycyjno-budowlanego. Uwarunkowania. Bariery. Perspektywy, Warszawa 2009.

Rabska T., Działania administracji publicznej w świetle współczesnej koncepcji publicznego prawa gospodarczego, [w:] B. Popowska, K. Kokocińska, Instrumenty i formy prawne działania administracji gospodarczej, Poznań 2009.

Rzetelska K., Wycofanie się państwa z publiczno-prawnego wykonywania zadań, PUG 2004.

Schmidt-Aßmann E., Ogólne prawo administracyjne jako idea porządku. Założenia i żądania tworzenia systemu prawa administracyjnego, Warszawa 2011.

Skoczyński T., Ustawa o partnerstwie publiczno-prywatnym. Komentarz praktyczny, Lex/el 2011.

Skrzydło W., Konstytucja Rzeczypospolitej Polskiej, Kraków 2002.

Wierzbowski B., Gospodarka nieruchomościami. Podstawy prawne, Warszawa 2010.

Zacharko L., Prywatyzacja zadań publicznych w nauce niemieckiej, ST 1996, nr 3. 


\title{
THE IMPLEMENTATION OF THE PRINCIPLES \\ OF SUSTAINABLE DEVELOPMENT THROUGH THE INTERACTION OF PUBLIC AND PRIVATE INTERESTS
}

\begin{abstract}
Above all the implementation of sustainable development requires the cooperation of public and private interests dedicated to fulfilling its principles. The purpose of this paper is to show how this relationship can be shaped and what goals related to the principles of sustainable development are subsequently achieved as a result. It is only cooperation between public administration and private entities that allows for consistent and effective development of all areas relevant to the above principle. This is particularly the context of cooperation between public administration and business in the public-private partnership, as well as nongovernmental organizations. So shaping these relationships is guaranteed to promote widespread impacts of this principle, thus achieving its established goals.
\end{abstract}

Keywords: public interest, private interest, the interaction of interests, publicprivate partnerships, NGOs 